\title{
Omzien in verwondering
}

Citation for published version (APA):

van Dieijen - Visser, M. P. (2020). Omzien in verwondering: Afscheidsrede. Maastricht University. https://doi.org/10.26481/spe.20200930md

Document status and date:

Published: 30/09/2020

DOI:

10.26481/spe.20200930md

Document Version:

Publisher's PDF, also known as Version of record

\section{Please check the document version of this publication:}

- A submitted manuscript is the version of the article upon submission and before peer-review. There can be important differences between the submitted version and the official published version of record.

People interested in the research are advised to contact the author for the final version of the publication, or visit the DOI to the publisher's website.

- The final author version and the galley proof are versions of the publication after peer review.

- The final published version features the final layout of the paper including the volume, issue and page numbers.

Link to publication

\footnotetext{
General rights rights.

- You may freely distribute the URL identifying the publication in the public portal. please follow below link for the End User Agreement:

www.umlib.nl/taverne-license

Take down policy

If you believe that this document breaches copyright please contact us at:

repository@maastrichtuniversity.nl

providing details and we will investigate your claim.
}

Copyright and moral rights for the publications made accessible in the public portal are retained by the authors and/or other copyright owners and it is a condition of accessing publications that users recognise and abide by the legal requirements associated with these

- Users may download and print one copy of any publication from the public portal for the purpose of private study or research.

- You may not further distribute the material or use it for any profit-making activity or commercial gain

If the publication is distributed under the terms of Article $25 \mathrm{fa}$ of the Dutch Copyright Act, indicated by the "Taverne" license above, 


\section{Omzien in verwondering}

Leden van de Raad van Toezicht en de Raad van Bestuur van het Maastricht UMC+, leden van het College van Bestuur van de Universiteit Maastricht, gouverneur van Limburg, beste collega's, familie en vrienden, van harte welkom bij deze gelegenheid en natuurlijk welkom aan iedereen die via de livestream meekijkt. Ik voel me vereerd met uw komst en belangstelling, zeker in deze corona-tijd.

Toen ik voor het eerst al eens een beetje nadacht over een afscheidsrede was er helemaal nog geen sprake van corona. Ik heb toen aan een aantal onderwerpen gedacht. Ga ik het hebben over klinische chemie? Maar ja, ik mag mij inmiddels geen klinisch chemicus meer noemen. Ga ik het hebben over mijn wetenschappelijk onderzoek aan hartmerkers, troponine? Over de toekomst van de gezondheidszorg of over academisch leiderschap? Uiteindelijk heb ik - nog in het pre-corona-tijdperk - besloten het niet te inhoudelijk te maken en samen met u terug te kijken en te reflecteren op dingen waarover ik mij verwonder of verwonderd heb, en besloot ik mijn rede 'omzien in verwondering' te dopen. Niet wetende dat de grootste verwondering en de grootste uitdaging op het gebied van leiderschap nog moest komen en dat van rustig afbouwen in de laatste maanden geen sprake zou zijn.

Ik ga eerst even met $u$ terug in de tijd. Terugkijkend is mijn grootste verwondering misschien wel dat ik hier vandaag überhaupt sta. Als iemand mij aan begin van mijn carrière had gevraagd 'wat zijn je ambities?', kan ik u verzekeren dat voorzitter van de Raad van Bestuur van het Maastricht UMC+ zelfs in mijn stoutste dromen niet zou zijn voorgekomen. Ook toen ik hoogleraar en afdelingshoofd Klinische Chemie werd in 1993 en ik mijn sollicitatiegesprekken met Jan Carpay, de toenmalige voorzitter azM, voerde, was zijn baan zeker niet het station dat ik voor ogen had.

En bij die eerste verwondering moest ik terugdenken aan een prachtige zin die ik ooit gelezen heb. 'Als ik mezelf niet was, maar wel kende, zou ik jaloers zijn op mezelf' (M Höweler). Mooier kun je niet uitdrukken dat je je bevoorrecht voelt en dat is wat ik - terugkijkend - voel. Bevoorrecht om de dingen die ik heb mogen doen, om de carrière die ik vandaag officieel afsluit. Maar ik vind die zin ook mooi, omdat hij twee aspecten uitdrukt. Enerzijds bevoorrecht te zijn, maar tegelijk ook dat het van een afstand gezien vaak mooier en imposanter lijkt dan het in werkelijkheid is.

\section{Promotie}

I $\mathrm{k}$ neem $\mathrm{u}$ mee in mijn verwondering en tijdens die reis neem ik $\mathrm{u}$ ook mee langs de mensen die bijgedragen hebben aan mijn loopbaan, want je doet het niet alleen. Ik doe dat ook, opdat ik aan het einde niet nog heel veel mensen moet bedanken, maar dat ondertussen al doe. We leven per slot van rekening in een tijd waarin we altijd 'ondertussen' iets anders doen.

Ik ga eerst even met $u$ terug naar mijn promotietijd. Ik vond promoveren eigenlijk helemaal niet zo leuk. Ik heb daar nooit een geheim van gemaakt. Dat lag absoluut niet aan mijn begeleiders, Wim Hermens en Coen Hemker. Ik had meerdere dimensies nodig. Ik herinner mij nog het moment dat ik dit bekende aan mijn promotor Coen Hemker en dat hij op de labtafel ging zitten, terwijl ik met mijn experimenten bezig was en zei, "ach weet je: promoveren, ' $t$ is eigenlijk een jeugdzonde. Ofwel je doet er nooit meer iets mee en dan moet je er zo snel mogelijk vanaf, ofwel onderzoek wordt je passie". En vervolgens dacht hij met me mee en raadde hij mij de klinische chemie aan. Dat is wat een goede begeleider doet, zich verplaatsen in de ander. Het was een vakgebied waar ik nog nooit van had gehoord en waar je zonder kruiwagen niet tussen kwam. Zeker niet als vrouw. En een 
Prof. dr. Marja van Dieijen-Visser

Faculty of Health, Medicine and Life Sciences

\section{Omzien in verwondering}


eventuele kinderwens moest je vooral verzwijgen. Inmiddels is bijna de helft van de klinisch chemici vrouw, om ondertussen een hele positieve verwondering uit te spreken.

Ik ben prof. dr. Coen Hemker en prof. dr. Paul Brombacher, mijn opleider klinische chemie, die helaas begin juli is overleden, nog altijd heel dankbaar dat zij deze route voor mij mogelijk hebben gemaakt. Ik voel me nog steeds klinisch chemicus, ook al heb ik mijn brevet door het besturen moeten opgeven.

\section{Klinische chemie/ laboratoriumgeneeskunde}

Voor diegenen die het vak niet kennen. Klinische chemie/ laboratoriumgeneeskunde is de analyse van lichaamsvloeistoffen voor diagnostiek, behandeling en follow-up van ziektes en de interpretatie van de uitslagen. Daarnaast ben je als klinisch chemicus verantwoordelijkheid voor de organisatie van het laboratorium, inclusief het personeelsmanagement.

In feite is het de constante uitdaging om van afname van het materiaal tot aan de uitslag in zo kort mogelijke tijd tot een goed en betrouwbaar resultaat te komen. Ik vind het een prachtig vak met veel dimensies, waardoor je je kunt toeleggen op dat deel van het vak waar jouw affiniteit ligt.

Patiëntenzorg, onderzoek, onderwijs/opleiding, management, logistiek of ICT, want per dag moeten duizenden monsters worden afgenomen en geanalyseerd. Een ander groot voordeel vind ik dat je al vanaf het begin van je opleiding veel in aanraking komt met management, leidinggeven aan teams en wat daarbij komt kijken. Dat je in een vroeg stadium leert dat leidinggeven aan een team, ook veel dagdagelijks, intermenselijk gedoe betekent, en dat je dat ook leuk moet vinden, van mensen moet houden, anders moet je het vooral niet doen. Dat in zo' $n$ afdeling veel draait om je voorbeeldfunctie. Hoe serieus je die neemt, is de basis om geloofwaardig te zijn. Die praktische ervaring met integraal management van een afdeling is iets waarin laboratoriumspecialisten zich onderscheiden ten opzichte van andere medische specialismen. Ik beschouw dat als een groot voordeel. Door die integrale verantwoordelijkheid voor personeel en organisatie heb ik enorm veel mogen leren over logistieke processen, ICT en over leiderschap. Zo denken we bij leiderschap altijd aan de top. Maar als ik uit mijn klinische-chemietijd iets heb geleerd, is het dat er op elk niveau goede leiders zijn. Mensen die bij uitstek geschikt zijn om op een respectvolle wijze een team aan te sturen. Ook dat zijn de leiders waar een organisatie op draait. Die daar een oergevoel/ instinct voor hebben. Leiderschap gaat ook over echte aandacht en empathie. Goed in je vak zijn, maakt je niet per definitie een goede manager of leider. $U$ denkt vast: wat een open deur, maar ik heb er in al die jaren te veel afdelingshoofden mee zien worstelen of sneuvelen. Terwijl ze top waren in hun vak, een hoge Hirschfactor en internationaal aanzien hadden, maar als het op aansturen van een team of vakgroep ging, ze het niet vanzelfsprekend redden. Dat is een verwondering, geen waardeoordeel. Het is wel iets waar we als UMC's nog meer mee moeten. Het VSNU-rapport erkennen en waarderen, waarbij we het top in je vak zijn als dominante factor voor waardering nuanceren, gaat daar zeker bij helpen.

\section{Technologie als stuwende kracht van vooruitgang}

Klinische chemie heeft me nog iets heel belangrijks geleerd. Namelijk dat technologie, een enorm belangrijke stuwende kracht, zo niet de stuwende kracht is voor veranderingen. Deze slide geeft een indruk van de verandering zoals ik die gezien heb vanaf 1981, de start van mijn opleiding in Heerlen, nu Zuyderland, tot 2020 Maastricht. Van mechanisering via automatisering naar robotisering. Omdat we in alle vakgebieden op moleculair niveau meten, zijn de laboratoria zijn niet meer alleen naar discipline, maar steeds meer naar techniek ingericht. De ontschotting zoals we die realiseerden, was destijds voor een UMC bijzonder. Ik ben er trots op dat ik het voortouw heb mogen nemen in de 
vorming van een centraal diagnostisch laboratorium, en op de wijze waarop mijn opvolger prof. $\mathrm{dr}$. Otto Bekers dat weer verder vorm heeft gegeven. Het is goed om je te realiseren dat veel van de huidige transities in de zorg in de basis technologie-gedreven zijn. In mijn lezingen laat ik vaak twee plaatjes zien. Het ziekenhuis toen en nu.

Het oude Calvariënberg: het voornaamste wat we te bieden hadden, was zorg, bedrust, antibiotica. Je kon rustig je pijpje roken op zaal mannen en vrouwen door elkaar, inclusief het gezellige, gehaakte kleedje.

Dit is gechargeerd de zorg van nu: sterk technologie-gedreven, zo kort mogelijk verblijf en de toekomst zal zijn: wat je zelf kunt, zelf doen. Technologie en innovatie staan aan de basis van grote maatschappelijke transities. Dat deed mij ook terugdenken aan mijn eerste baantje. Dat was niet in de kroeg - wie mij kent, zal dat niet verbazen - maar student-assistent bij het rekencentrum in Leiden, waar ik als ondersteunend computerprogrammeur meewerkte aan EEG-analyse bij het slaapwaakritme. Eindeloos op de fiets naar het rekencentrum om een set ponskaarten in te lezen. De rekencapaciteit van het hele mathematisch instituut past nu met gemak in uw laptop. Als ergens in het ziekenhuis veel over wordt geklaagd, is het de ICT. Soms is het ook goed om je over het goede te verwonderen, zonder je ambities bij te stellen. Voor de toekomst hebben we een nog duidelijker digitale strategie nodig.

Ik heb me ook gerealiseerd dat, als we ons iets nog niet helemaal kunnen voorstellen, dat we dan als vakspecialist al te vaak in de ontkenning schieten: nee dat kan nooit! Vooral als het een bedreiging voor onze autonomie kan betekenen. Zo ook jaren geleden, toen iemand mij suggereerde dat we de bloedafname ook konden automatiseren. Je steekt je arm in een loket en verder gaat het automatisch. Het leek me volslagen ridicuul, maar zie hier: er wordt aan gewerkt.

Zeker als bestuurder moet je altijd op je hoede zijn voor ontwikkelingen waarvan je denkt dat ze onmogelijk zijn. De snelheid waarmee wij beeldbellen en thuiswerken in coronatijd hebben doorgevoerd, hadden u en ik niet voor mogelijk gehouden en gaat grote consequenties hebben, bijvoorbeeld voor de omvang van de ziekenhuizen. Voor grote transities blijkt bijna altijd een sense of urgency of trigger nodig te zijn.

Er staat ons nog een veelheid aan nieuwe ontwikkelingen te wachten. Bijvoorbeeld op het gebied van algoritmes en deep learning. Algoritmes om besluiten te nemen zijn niet nieuw. Die gaan ons nog beter ondersteunen en taken van ons overnemen, zo niet dingen beter doen dan wij. We moeten de kracht van artificial intelligence en deep learning niet onderschatten. Neem het project debater van IBM, in een kwartier is debater expert op elk gebied, door 400 miljoen krantenberichten door te spitten, de overtuigende claims eruit te halen en er een verhaal van te maken. Nog lang niet perfect, maar we zullen nog versteld staan van wat gaat kunnen. Met een dochter die gepromoveerd is op natural language processing, heb ik hier iets meer zicht op gekregen, ook op de beperkingen.

Of neem 3D printing, zodat uw knie of heupgewricht beter past, kleppen die op maat gemaakt kunnen worden. Robots die het menselijk denken nabootsen. Doordat we meestal reflecteren op een korte periode, onderschatten we voortdurend de snelheid van de vooruitgang en de maatschappelijke transities die erbij horen. Heel goed dat de UM onder leiding van Martin Paul steeds meer inzet op science en technology en datascience. Dat door de provincie volop wordt ingezet om de Einstein-telescoop naar Limburg te krijgen. 
Maar al die technologie heeft ook een keerzijde. Het maakt ons ook kwetsbaar en dit beeld herkennen we allemaal: de dokter, verstopt achter zijn beeldscherm. Ook een gevolg van technologie. Uiteindelijk gaat zorg primair over de interactie en de echte verbinding tussen mensen.

\section{Combinatie van technologie en biomedische ontwikkelingen}

Het is niet alleen techniek, maar de combinatie van techniek en biomedische ontwikkelingen die bepalend is voor de vooruitgang. We willen de chemische fabriek die wij zijn, ontrafelen en na kunnen maken. De ontwikkeling van genoom-, metaboloom- en proteoomanalyse voor de diagnostiek heb ik in de klinische chemie volop meegemaakt. Ook hier breekt weer een nieuw tijdperk aan. Een jaar voor ik geboren werd (1953), werd DNA ontdekt, nog maar zo kortgeleden. In 2003 was na dertien jaar de volgorde van drie miljard baseparen in kaart gebracht, dat kunnen we nu in één week! En met de CRISPR/cas-technologie zijn we aan het leren het genoom te herschrijven, genetische foutjes te repareren. Dat gaf in 2018 felle discussies over een genetisch gemanipuleerde baby in China. Maar vooruitgang is nu eenmaal niet te stoppen, we zullen geconfronteerd worden met de ethische aspecten ervan en moeten ons er nu al op voorbereiden.

In mijn periode als directeur-bestuurder van de RVE Beeldvorming en Laboratoria heb ik veel van die ontwikkelingen op de voet kunnen volgen. Van distributierobot in de apotheek, de ontwikkeling in beeldvormende technieken, de aanzet tot digitale pathologie en snelle detectie van microorganismen. Op het gebied van leiderschap heb ik daarbij voor eerst echt ervaren dat bij grotere transities, zoals ontschotting en gezamenlijk gebruik van gemeenschappelijke platforms, waar verlies van autonomie optreedt, een trigger noodzakelijk is om grote transities te realiseren. Desnoods moet je een trigger creëren. In de Euregio ervoeren we de druk van commerciële buitenlandse laboratoria veel eerder dan elders, daardoor zagen we de noodzaak van het gezamenlijk inzetten van platforms ook eerder. Die druk van de markt heeft zeker geleid tot een andere, klantvriendelijkere en economischere opstelling van de laboratoria. Hoeveel tijd en energie het doorvoeren van grote transities in publieke organisaties kost, is nog altijd een grote verwondering voor me. Bovenal heb ik een fantastische tijd gehad samen met de afdelingshoofden en medewerkers en hebben wij veel kunnen realiseren.

Toponderzoek vereist topinfrastructuur en focus. Mooi voorbeeld vind ik hoe we met alle partijen Imaging Valley hebben ingericht. Samen met provincie, ziekenhuis, universiteit en Maastro hebben we het mogelijk gemaakt dat we een top-infrastructuur op onze campus hebben op het gebied van beeldvormende technieken, waardoor we ons echt kunnen onderscheiden.

\section{Wetenschappelijk onderzoek}

Wetenschappelijk onderzoek ben ik pas leuk gaan vinden toen ik in de klinische chemie terecht kwam en ik het onderzoek uit mijn promotietijd op het gebied van hartmerkers kon toepassen. Mijn promovendi zijn bijna allemaal de klinische chemie ingegaan, en zijn bepalend voor het succes van het onderzoek. Onderzoek is teamsport en vraagt een heel ander soort leiderschap. Je wordt als leider pas geaccepteerd als je over de inhoudelijke kennis en expertise beschikt. Met $z^{\prime} n$ allen hebben we gewerkt aan de ontrafeling en de mogelijkheden voor diagnostiek van het harteiwit troponine. 25 jaar onderzoek aan één enkel eiwit. De pitfalls bij het bepalen ervan vertonen veel parallellen met het analyseren van het corona-virus of de antilichamen ertegen. Wat meet je precies, hoe gevoelig, wat heb je eraan, wat is het verschil tussen de testen van verschillende fabrikanten? Realiseren we ons dat bij het screenen van grote, relatief gezonde populaties meer vals-positieve resultaten voorkomen. Zo ook bij veel testen van covid-19. 
Vaak heb ik gedacht aan de bekende fabel van de blinde mannen en de olifant. Zes blinde reizigers die op hun levensweg tegen verschillende delen van de olifant aanlopen, maar niet doorzien dat het een olifant is, omdat zij het geheel niet zagen. Ondanks de vele, vele goede stappen die we hebben gezet, weten we nog steeds niet of troponine de hartspiercel kan verlaten zonder dat celdood optreedt. We weten wel dat de concentraties toenemen na het lopen van een marathon, maar wat er daadwerkelijk gebeurt, hebben we nog niet ontrafeld. Ik gebruik het dus nog steeds als argument om geen marathon te hoeven lopen.

Dankzij de Weijerhorst-subsidie en doordat bijna alle stafleden betrokken waren bij dezelfde onderzoekslijn, hebben we echt grote stappen kunnen maken en zijn we internationaal van betekenis. Het heeft me geleerd dat je kritische massa nodig hebt om echt tot resultaat en internationale erkenning te komen.

\section{Bestuurder umc}

En toen kwam de keuze om weg te gaan van de inhoud. Ik heb altijd gezegd: ik wil wel bestuurder worden, maar alleen in een umc. Veel dank aan mijn collega's in de RvB in wisselende samenstellingen. Ik houd van de academie, van de mensen die er werken, die passie hebben voor patiëntenzorg, gecombineerd met onderzoek en onderwijs, het opleiden en vooral het contact met jonge mensen. Het feit dat je mensen vanwege hun ambities eerder moet afremmen dan stimuleren, maakt het uitdagend.

Wat doe je nou eigenlijk als bestuurder van een umc is me vaak gevraagd. Het is een baan zonder bijsluiter en ik gebruik regelmatig de slogan: 'mensen willen zo lang en gezond mogelijk leven, ze willen goede kwaliteit van zorg, maar ook een betaalbaar stelsel, oftewel een zo laag mogelijke zorgpremie'. Balanceren tussen deze elementen bij het maken van keuzes is wat je als bestuurder doet om duurzame zorg te realiseren. Grote uitdaging daarbij is de gezondheidskloof tussen hoog en laagopgeleiden te dichten.

Als Maastricht UMC+ werken we al ruim tien jaar vanuit de visie dat we naast onze opdracht om mensen beter te maken, ook moeten werken aan het behouden van een goede gezondheid en het bevorderen ervan. Het motto van onze strategie: 'Gezond Leven', is al ingezet door mijn voorganger Guy Peeters en geeft dit nadrukkelijk weer. Daar zetten we al jaren fors op in en het staat ook weer prominent in onze strategie tot 2025. In de wetenschap dat 'gij zult gezond leven' niet gaat werken, moeten we samen met industrie en overheid mensen verleiden gezonder te leven. Mijn collega prof. dr. Albert Scherpbier heeft daar in de Raad van Bestuur samen met de NFU het voortouw in genomen. In Limburg hebben we hier een grote uitdaging, die momenteel actief door alle partijen wordt opgepakt. leder vanuit de eigen expertise: gemeente, provincie, universiteit en ziekenhuis. Samen met al die partijen hopen we de zorg te verbeteren en de kloof te dichten.

We hebben ingezet op een heldere strategie en je daaraan committeren heb ik hoog in het vaandel gehad. We hebben er steeds voor gekozen samen de strategie te bepalen, bottom-up.

Strategieontwikkeling als co-creatie. Geen top-down besluitvormingsproces, maar samen met je eigen mensen de toekomst bouwen. Dat kost wel tijd! Democratie kost tijd is daarbij mijn motto.

Met als kader dat we de uitdagingen zoeken in díe aspecten die ons uniek maken, anders dan andere umc's: Het enige umc dat zowel stadsziekenhuis als umc is, maak daar ook je kracht van. Door zorg en onderzoek over de hele keten te doen, van de $0^{\text {de }}$ tot de $3^{\mathrm{e}}$ lijn, dat moeten we uitbuiten. De transmurale zorg. Wij zijn bij uitstek geschikt als proefregio voor geïntegreerde regionale zorg. 
Ondoenlijk hier in kort bestek op alle elementen van die strategie in te gaan. Trots ben ik op het continue verbinden van zorg, onderzoek en onderwijs, de innovatiecirkel, het instrument om dit zichtbaar te maken, ik noem hem toch even. De themagerichte organisatie van het facultaire onderzoek en een geïntegreerde faculteit geneeskunde en biomedische wetenschappen heeft dat mogelijk gemaakt. Trots ben ik op onze samenwerking met de regio, op de academische alliantie met Nijmegen, de samenwerking met Aken, maar ook op de doorontwikkeling van de Brightlands Maastricht Health Campus met diverse nieuwe startups, en op onze rol als academische motor in de regio.

En dan de transformatie van de organisatie. De organisatie zo inrichten dat zij het beste bij onze ambities past. Daar hebben we het laatste jaar heel veel energie in gestoken. De inrichting van centra met geïntegreerde zorg over de hele keten. De patiënt steeds meer zelf aan het stuur, alles rond de patiënt organiseren en waar mogelijk van huis uit. Waarbij we niet meer denken in termen van mijn bedden, mijn infrastructuur, mijn medewerkers, maar veel meer delen, zodat we er samen maximaal waarde uit halen. Optimaal capaciteitsmanagement met een duidelijker rol voor de verpleging. De basis ligt er en ik ben ervan overtuigd dat de nieuwe Raad van Bestuur onder leiding van Helen Mertens dit samen met de organisatie verder vorm gaat geven, maar er ligt nog een grote uitdaging.

Er natuurlijk waren er 'wakker-lig'-dossiers. Ik noem zeker het stoppen met de bouw van gezondheidscentrum Mosae Vita, het IT-transformatieprogramma en de besluitvorming rond het elektronisch patiëntendossier (epd), om er een paar te noemen.

Belangrijk verschil tussen de bestuurder en de vakspecialist is dat je als bestuurder vaak aan tafel zit met mensen die kennis en expertise hebben waar jij veel minder of soms geen kaas van hebt gegeten. Je moet voortdurend informatie bundelen en filteren en voorwaarden scheppen zodat anderen en de organisatie kunnen groeien. Openstaan voor andere inzichten en niet alleen maar zoeken naar feiten die je eigen inzichten staven en toch constructief kritisch blijven is voortdurend de uitdaging. Dat het echt mis kan gaan, geef ik aan met een voorbeeld uit mijn eigen vakgebied. Een extreem voorbeeld kan bij ons niet voorkomen, maar het laat wel het beste zien wat ik bedoel.

Ik heb u net verteld dat we 25 jaar bezig zijn geweest met het ontrafelen van één enkel eiwit, troponine, en hoe lastig betrouwbaar analyseren kan zijn. We zien het nu ook bij COVID-19. Een paar jaar geleden kwam Elisabeth Holmes met haar revolutionaire idee van een nieuwe, snelle manier van bloedtesten. Ze beweerde over een volstrekt nieuwe technologie te beschikken om in een paar microliter bloed 200 tests te kunnen bepalen. Er was argwaan, in het hele beroepenveld, bij de industrie, maar al in het eerste jaar haalde Holmes met haar charmes het ongekende bedrag van 45 miljoen dollar op voor haar bedrijf Theranos, en haar portret prijkte in alle businesskranten. Ik haal het aan omdat zo veel invloedrijke mensen er geld in investeerden (Clinton, Kissinger etc.), waardoor ook klinisch chemici gingen twijfelen; misschien heeft ze toch wel iets, terwijl we voelden dat het niet kon. Haar bedrijf bleek gebaseerd op leugens en vervalste testresultaten in verdunde monsters die op gangbare apparatuur waren bepaald. Het heeft zo kunnen gaan omdat ze categorisch de echte experts buiten de deur hield. Leiderschap gaat ook over je moreel kompas en kritisch blijven.

\section{Wat had beter gekund}

Ik heb het aan het begin al even gehad over een positieve verwondering. Het aantal vrouwen in de klinische chemie is inmiddels $45 \%$. Ook het aantal vrouwen in ziekenhuisbesturen gaat de goede kant 
op, rond de $40 \%$. Maar het aantal vrouwelijke medische afdelingshoofden is nog bedroevend laag, $11 \%$. Daar staan we nog voor grote uitdaging.

\section{En toen kwam corona}

En toen kwam corona. 25 juni zou ik met pensioen gaan, door corona is het een paar maanden uitgesteld. Een enerverende periode die 'nog niet voorbij is' en zeker de geschiedenisboeken in zal gaan. Er wordt veel gezegd en volop geoordeeld. We worden overspoeld met een kakofonie aan opinies over dingen die we in feite niet weten. Ik houd het voor nu even bij de quote: 'Het leven kan alleen achterwaarts begrepen worden, maar het moet voorwaarts worden geleefd' (Kierkegaard). Dat geldt bij uitstek voor een wereldwijde crisis als deze.

Ik ben blij dat ik er samen met de medewerkers van het umc aan heb mogen bijdragen en heb kunnen zien waar we met $z$ ' $n$ allen toe in staat zijn als het moet. Bewondering en diep respect voor iedereen, ook voor de thuiswerkers. In het begin de spanning en zorgen rond persoonlijke beschermingsmiddelen, de inventiviteit, het inrichten van de triagetent, het inrichten van het MECC, het waren topprestaties. En inderdaad: we hebben het MECC niet nodig gehad. 'Better safe than sorry' hebben we gezegd, we doen het en hopen dat het niet nodig is. We hebben geen Italiaanse of New Yorkse toestanden gekend, maar wel veel momenten waarin de spanning groot was om een veelheid van redenen. We zien nu ook hoe meer de angst verdwijnt, des te meer wordt ontkend dat de dreiging reëel was. Zo ook de achterafbeoordeling van het MECC. Ik blijf er trots op.

De crisis maakt wederom duidelijk dat onder druk grote transities tot stand komen. Toch weer die sense of urgency die om de hoek komt kijken. Ontwikkelingen waar we normaal jaren voor nodig hadden waren in één klap gerealiseerd. Telemonitoren, beeldbellen, thuiswerken, waar ik nooit een voorstander van was, het kon/moest ineens. Mensen werden heel snel digitaal vaardig.

Wat als we over een aantal jaren de balans opmaken van de coronacrisis? Zullen we verwonderd of verbijsterd zijn, ik weet het niet. Hoe groot zullen de komende jaren de gevolgen van deze crisis zijn? Lockdown of intelligente lockdown, was het de goede strategie? Is de rest van de zorg te lang tot stilstand gekomen? Moeten we de zorg voorrang geven boven alles, ook de economie? Zijn we voorbereid op een tweede golf en is er voldoende personeel? Hebben mondkapjes zin? Was het juist om geen bezoek toe te staan? Op sommige vragen heb ik met de kennis van nu wel degelijk een antwoord of een mening. Bij voorkeur niet meer alle zorg stilleggen en ja, wél bezoek toelaten met voldoende bescherming. We hebben geleerd, steeds aangepast en zijn beter voorbereid, althans dat denk en hoop ik.

Maar wie ben ik, ik was erbij net als u. Daarom memoreer ik een prachtige passage uit een van mijn lievelingsboeken: 'Alsof het voorbij is' van Julian Barnes. 'Als we terugkijken zullen we de geschiedenis van de geschiedkundige moeten kennen om de versie die ons wordt voorgelegd te begrijpen'. Dat geldt ook voor mijn verhaal dat vooral gekleurd is door mijn eigen ervaring en verwondering. Over een jaar of vijftien kijkt Helen ook weer om, misschien met nog meer verwondering dan ik nu. Ik heb in elk geval groot vertrouwen in mijn opvolgster.

\section{Dankwoord}

Ik kom aan mijn dankwoord. Zoals gezegd, het is ondoenlijk iedereen bij naam te noemen. Een paar kan ik niet laten, Lucie Paffen van de klinische chemie en Annette Vleugels van de Raad van Bestuur, omdat zij al die jaren mijn dagelijkse werkzaamheden perfect hebben georganiseerd. Ik dank de Raad 
van Toezicht van het Maastricht UMC+ voor het vertrouwen in mij, het College van Bestuur en mijn collega's in de Raad van Bestuur en vooral veel dank aan iedereen waar ik afgelopen jaren mee heb mogen samenwerken.

Natuurlijk mijn familie, waar ik super, super trots op ben. Zij hebben mij gevormd tot wie ik ben.

Ik heb gezegd.

Prof. dr. Marja van Dieijen-Visser, 30 september 2020 